WIELKIE TEMATY KULTURY W LITERATURACH SŁOWIAŃSKICH

Slavica Wratislaviensia CLXVIII • Wrocław 2019•AUWr No 3875

DOI: 10.19195/0137-1150.168.36

Data przesłania artykułu: 12.06.2017

Data akceptacji artykułu: 30.11.2017

\author{
MIRJANA AREŽINA
}

Универзитет у Бањој Луци, Bośnia i Hercegowina

\title{
Рефлексије о смрти у Ремети другој дубровачког пјесника Мавра Ветрановића
}

Иако је с појавом хуманизма и ренесансе човјек постављен у центар свега, постао „субјекат”, што је свакако било другачије него у средњовјековном периоду, медиевистичка филозофија није се изгубила. Њене теме само су обрађене на другачији начин - у оквиру хришћанске ренесансе, посебне стваралачке струје која је религиозни садржај прилагодила новој, ренесансној форми. Дубровачки пјесник Мавро Ветрановић (1482-1576), као представник хришћанске ренесансе, у побожним драмама прерађивао је теме из Старог и Новог завјета, препјевавао је покајничке псалме, а један од битних видова „трајања“ средњег вијека био је и пјесников однос према ништавости овоземаљског живота, те размишљања о смрти, као неминовности.

Смрт је била честа тема Ветрановићеве поезије (Пјесанца размишљања о смрти, Пјесанца смрти, Пјесанц̧а кратку року нашега живота). У својим размишљањима о смрти Ветрановић нема јединствен став - у појединим пјесмама представља је као казну, док је у другим она нада и избављење. Пјесник сматра да ће му смрт донијети прочишћење и ослободити га свих мука, осјетиће жељено спасење (Пјесанияа смрти, Свијет и моје пјесни, Моја плавцฺа, Тужба моја, Пјесаниза Нептуну, Пјесани̧а несрећи). Жели да остави таман свијет и да Исусу дође „од злоба свиех опран” (Пјесанц̧а $J е c y c y)$, да се избави „минутијех свијех јада” (Моја плавцуа) и ослободи од „тмасте мрклости” (Свијет и моје пјесни). Међутим, у појединим пјесмама јасно је изнио страх од смрти и тјелесног распадања (Тужба моја, Пјесанца размииљььь од смрти). Описао је њену неминовност (Свијет и моје пјесни), бесмисленост богатства (Млохаво је световно уфан’је, Тужба краља Давида врху Абсалона), наглашавајући да су сва задовољства пролазна, док је смрт 
казна за охолост (Пјесаниа размишљања од смрти). Смрт се „влада химбено крадући”, човјек увијек мора бити свјестан да ће умријети (Пјесанца кратку року нашега живота), смрт треба прихватити као Божију вољу (Пјесанща размиильања од смрти).

Ремета друга, испјевана у 416 осмераца, најпознатија је Ветрановићева сатирична пјесма. Злата Бојовић истиче да је ова пјесма садржала програм великог дијела Ветрановићеве сатиричне поезије, те да се у тој поезији усредсредио на друштвене и људске пороке како би показао надмоћ хришћанске идеје и вјечног живота над пролазним задовољствима. ${ }^{1}$ У складу са овим ставом примјетно је да, иако Ремета друга припада свјетовној лирици, њена функција јесте, између осталог, и изражавање религиозне ноте. Рефлексије о смрти у Ремети другој резултат су Ветрановићеве филозофије, која се темељила на хришћанским начелима и учењима. У пјесми је описао човјекову ништавост, пролазност живота и свих овоземаљских добара, неминовност умирања, као и једнакост свих пред смрћу. У уводном дијелу пјесме објашњава да је дошао у близину града да би научио Дубровчане како треба живјети, те да им укаже на прави начин избављења од охолости и таштине. На самом почетку ограђује се од моралисања које слиједи, па наглашава да преноси Божије ријечи, свјестан да ће од поражавајуће истине коју чују, њихове власи „потрептати на глави”.

Да ће се у својим ставовима ослањати на Свето писмо и хришћанску концепцију живота, било је јасно, јер је већ на почетку пјесме, прије него што је изнио властита размишљања, парафразирао дио из Старог завјета. Соломонове мисли: „Ко ходи право, боји се Господа; а ко је опак на својим путовима, презире га”. (14: 2) $)^{2}$; „Пут је праведнијех уклањање ода зла; чува душу своју ко пази на пут свој”. (16: 17); „Ко држи заповијести, чува душу своју; а ко не мари за путове своје, погинуће”. (19: 16) - Ветрановић је прилагодио осмерцима:
Краљ Саламун ово вели:
разбирајте сви народи,
тко спасенје души жели,
вазда с Богом право ходи.“ 3

Затим, моралишући, наставља да проширује ову мисао. Објашњава кобне посљедице које чекају човјека ако је не слиједи. Почиње од општих рефлексија о смрти као казне, али и као избављења, па је, по пјесниковом мишљењу, најважније да човјек схвати да његов живот одређује његову смрт: „како чини дјело своје,/да напокон тач умира” (39-40). Увијек мора

1 Злата Бојовић, Историја дубровачке књижевности, СКЗ, Београд 2014, с. 116.

2 Sveto pismo Staroga i Novoga zavjeta, Biblija, Sveti arhijerejski sinod Srpske pravoslavne crkve, Beograd 2012. Стихови се наводе према овом издању.

${ }^{3}$ Pjesme Mavra Vetranića Čavčića, Dio I, Stari pisci hrvatski, knj. 3, Zagreb 1871, c. 25-28. Стихови се наводе према овом издању и сви наредни примери у загради садрже број странице. 
бити свјестан да ће умријети (29-36), а на ту неминовност убјеђује га опомињањем и пријетњом. Човјек је непрестано на граници, живот му вене као цвијет на трави, ${ }^{4}$ не може нигдје побјећи, смрт ће све окончати као што суво сијено изгори у пећи. Ова поређења преузета су из псалама, које је Ветрановић изузетно добро познавао, с обзиром на то да их је преводио: „Јер зна грађу нашу, опомиње да смо прах” (103: 14), „Дани су човјечији као трава, као цвијет у пољу, тако цвјета". (103: 15).

Један од начина да истакне човјекову ништавост (библијско „Ево, с педља дао си ми дане, и вијек је мој као ништа пред тобом. Баш је ништа сваки човјек жив" 39: 5) јесте и онај када успоставља релацију између прошлости, садашњости и будућности. Опомиње човјека да размисли шта је био и од чега је зачет прије него што се родио. Живући човјек (човјек у садашњости) споља и унутра, по Ветрановићевом поимању, чини склоп од двије супротности споља је лијеп, а унутра пун „смрда јак смрдећа врећа гноја“, док ће му за будућност бити потребна визија, односно треба да буде свјестан шта ће бити и гдје ће доћи „када буде к земљи прити и свјетовно благо оћи” (59-60).

Критика почиње благо, ставом да све имање, охолост и уљепшавање „на небеса не да прити”. Међутим, нагло прелази на окрутну слику црне глине створене од човјечијег распаднутог тијела и доласка у тамнило, када реторским питањем „би ли просуо благо твоје/ да ти се је повратити?” (79-80), готово иронично, потврђује некорисност материјалног. Наводи све човјекове гријехове због којих душа страда, а међу прве је уврстио раскош и блуд. Слике поменутих гријехова, разложених накнадно у пјесми, уклапају се у главне теме contemptus mundi, које укратко наводи Делимо, а присутне су код средњовјековних мислилаца: одвећ кратке овоземаљске радости рађају вјечне муке (Роже из Кана); земља је прогонство, „љубав према свјетовном животу је ноћ“ (Жан из Фекана); тијело је тамница (Филип Канцелар), човјек је „чедо трулежи“, а биће „храна црвима“ (непознати аутор из 11. вијека), чула, „биједни удес човјека“ јесу велики сводници који гурају људе у гријех (П. Дамијен). Ко жели да се спасе, ваља да „испљуне овосвјетску трулеж““ (П. Дамијен). ${ }^{5}$

Ветрановић поново прозива оне који се „топе у раскошах и у блуду”, наглашавајући да сва сјетовна добра треба одбацити, а међу првима „дику и гиздање". У литератури је већ примијећено да је црква узалуд подстицала људе средњег вијека да занемарују и презиру привидност и да траже права богатства која су скривена, а прва је привидност тијело. ${ }^{6}$ Сматрало се да га треба унизити. Овом ставу блиско је и Ветрановићево мишљење да тијело

${ }^{4}$ У пјесми Пјесанияа кратку року нашега живота опомиње човјека да је његов живот кратак, користећи исто поређење са цвијетом који вене: Чловјече а за тој чин' честе спомене, да је кратак живот твој, како цвиет ки вене; (43-44).

5 Ž. Delimo, Greh i strah, Stvaranje osećanja krivice na Zapadu od XIV do XVIII veka I, prev. Z. Stojanović, Novi Sad 1986, c. 22-23.

${ }^{6}$ Ž. Le Gof, Srednjovekovna civilizacija zapadne Evrope, prev. D. Stošić, Novi Sad 2010, c. 440. 
није за уљепшавање. Уљепшавању супротставља језиве слике неизбјежног краја:

Гладиш лица, гладиш косе, а не видиш са свијех страна мртва тијела гди проносе к земљи да су укопана. За клобуком носиш перје како паун тер се гиздаш, а не видиш туге веље тер сузице не пролијеваш. (93-100)

Да би био јаснији, све конкретизује визијом смрти која носи косу:

оштру косу гди смрт носи, са свијех страна тер интачно како сијено себе коси, толи трудно и толи плачно! (101-104)

и њом, „како сијено”, коси све редом: ${ }^{7}$ „краље, ћесаре, пјешце, коњике, младе, старе, књижнике, оружнике". 8 Ветрановић, у ствари, парафразира стихове из Пјесанще смрти:

И вриме не гледа нер косом ку коси,

Злосрдо без реда пред собом све коси (19-20)

${ }^{7}$ И ренесансни сликари представљали су смрт наоружану косом. Дирер ју је представио као костура на коњу који носи косу (British Museum, 1505).

У Рјечнику симбола (Ж. Шевалије, А. Гербрант, Рјечник симбола, прев. А. Буљан, Загреб, 1987.) наводи се да је коса симбол смрти, јер она, као и смрт, изједначава све живо. Да означи неумитно изједначавање, појављује се у рукама костура тек од 15. вијека. У Старом и Новом завјету то је срп који сијече коров и више је средство кажњавања него оружје смрти једнако за све. Срп или коса, слијепо оруђе које пресијеца све што живи, најчешће се налази у рукама старог Сатурна, хромог бога времена.

У Речнику симбола Х. Бидермана (Х. Бидерман, Речник симбола, прев. М. ТарарТутуш, Х. Чопић, М. Живановић, Београд, 2004) објашњен је симбол српа као прастарог жеталачког алата праисторијских земљорадничких култура млађег каменог доба, који се прво израђивао од камена. Касније је постао култни симбол, повезан са Мјесечевим српом (млади мјесец). Српом је у Хесиодовој Теогонији бог Крон кастрирао прабога Урана, прије него што је њега самог његов син Зевс оборио муњом, свргао са пријестола и прогнао. Срп је остао атрибут бога Крона, којег треба сматрати прехеленским богом плодности. Његово име касније је помијешано са персонификованим временом (Крон), које носи срп или (нешто млађу) косу, упућујући на неумољиво протицање животних доба. Управо из тог разлога срп и коса постали су и симбол смрти.

${ }^{8}$ Исти став износи и у Пјесанции смрти, истичући да смрт не бира, те пред њом сви падају:

и ние тај господар што на свиет бог сазда,

славан краљ ни чесар, ки при(д) њом не пада,

ни витез оружник, ки за час бије бој,

ни пјешац ни коњик, ки се не прида њој; (13-16)

Slavica Wratislaviensia 168, 2019

(C) for this edition by CNS 
и тиме показује да је исту мисао, исту слику у побожну сврху употријебио у сатиричној поезији.

И у наставку пјесме, у макабристичком духу, наводе се окрутне посљедице смрти, која не хаје ни за једну овоземаљску интимну везаност, јер раставља најближе: дијели браћу и сестре, љубавнике и љубавнице, сина и мајку. Тешко да се некадашња етничка реалија, коју доноси Ветрановић, а односи се на обредно-обичајну норму, обичајни код приликом обреда сахране (117-128), одржала у Дубровнику Ветрановићевог периода. Овај обичај короте у оквиру погребног, који подразумијева одсијецање косе („над гробови гди сузами/ подирају своје власе”) и нагрђивање лица (,,тер крваве нокти лице/у тужици и у вају”), више је у пјесми представљен метафорично да би се дочарао бол због губитка најдражих. ${ }^{9}$

Ветрановић сматра да је узалудно плакати и облачити се у црно, јер на тај начин не могу се повратити мртви. Људи, по његовом мишљењу, себи могу помоћи тако што ће се често подсјећати да су смртни, да ће „прјеђе много нер ли мните/гди је мирис тај смрдећи”(143-144), „опет голи, опет нази", бити у црној земљи. Смрт је немилосрдна, а људи не маре за то. Такође не хају за душу, већ ужвају у свим овоземаљским благодатима: плешу, пјевају, охоли су, облаче се у свилу и злато. Најбоља опомена за овакав живот јесте гробље, по којем треба проћи ,да жив видиш слику своју и јадовно огледало" (167-168). Слика коју развија пјесник, а која би требало да се нађе пред очима посматрача (гробља као огледала), односно закључак до којих треба посматрач да дође, у складу је са славном изреком, чије поријекло Делимо сматра да је арапско: „Што сам ја сада, они су били, a ја ћу бити оно што су они сада“. 10

Да би показао пропадљивост свих овоземаљских ствари, пјесник даје натуралистичку слику закопаних лешева: голе кости су у праху, и охоли и богати су се разагњили, гуштери и змије изгризли су лица. Човјек не треба да окреће главу од тог призора:

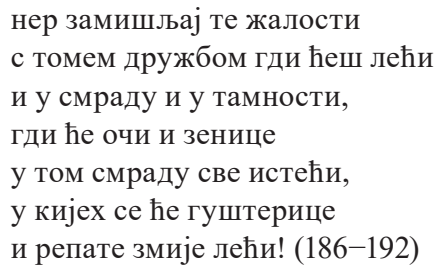

9 Закон 12 таблица из 450. године п. н. е. већ у том периоду забрањује нарицање и женама да гребу лице (поглавље 10, 3-4). У Црној Гори ови обичаји вјероватно су се дуже задржали јер Законик књаза Данила из знатно каснијег периода (1855) забрањује да се за мртвима шишају перчини и по образу гребу (89).

10 Ž. Delimo, Greh..., c. 67. 
У гробу ће само мало остати тога („,толи мала чљана и зглоба,/ки се неће растворити") што се неће распасти. ${ }^{11}$ Још једном наглашава бесмисленост свег овоземаљског добра (,чему бисер, чему свила...”); тијело, ма колико се уљепшавало, биће голо укопано. Критика савременика, у којој се илуструје и раскошно и преслободно одијевање Дубровкиња те украшавање различитим скупоцјеним накитом, огорчен је Ветрановићев позив на contemptus mundi. Ово његово размишљање и конкретно питање „Тијем, свјетовна ташта славо,/што испразно дни проводиш" (269-270) своди се на ријечи из Кьиге проповједникове (Све земаљько је таштина (прва глава)): „Таштина над таштинама, вели проповједник, таштина над таштинама, све је таштина“. Ватрановић парафразира многе мисли из друге главе Кюиге проповједникове. Реченице из поглавља Задовољство на земљи и весело уживање у раду таштина је: „Ја рекох у срцу свом: Дај да те окушам весељем; уживај добра“ (1), „Велика дјела учиних: Сазидах себи куће, насадих себи винограде;“ (4), „Начиних себи вртове и воћњаке...“(5), „Такође накупих себи сребра и злата...“ (8) - преточене су код Ветрановића у реторско питање:

Што ли зграде и полаче тач охоло ви градите, сву зеленцу и наранче у перивој тер садите $(281-284)^{12}$

Као контраст свјетовном уживању супротставља слику смрти, у циљу обезвређивања земаљских вриједности: наше голо тијело пребиваће у смраду, чело и обрве изгришће змије и црви, смрт ће наша тијела претворити

11 У пјесми Пјесанца размишљања о смрти описује страх од смрти и на исти начин описује пропадљивост тијела, које ће се претворити у прах и пепео и које ће изгристи црви и змије.

Пишући о мотивима распадања леша Делимо се позива на Шонија (P. Chaunu, La mort à Paris, XVI, XVII, XVIII siècles, Fayard, Paris, 1978) и његову тврдњу да је почетак књижевног и ликовног обрађивања мотива леша у распадању био повезан са „педагошком вољом неразлучивом од суђења (појединцу)“. Раније је црква нарочито инсистирала на васкрсењу тијела и душе крштених. То опште васкрсење евоцирано је у представама страшног суда. Напротив, стављањем акцента на леш који гризу црви, коначно васкрсење потиснуто је у магловиту даљину, а у први план је дошло поједниначно суђење души, одмах након смрти. Да би се та „антропологија одвојених душа могла развити, потребно је било убити тело“. Затим Делимо износи тврдњу Аријеса (Ph. Ariès, L’Homme devant la mort, Paris, Seuil, 1977) да тема страшног суда није била сасвим напуштена након 14. вијека, те да је налазимо у 15. и 16. вијеку у сликарству Ван Ајка или Х. Боша, а понекад и у 17. вијеку. Међутим, она је преживјела, изгубила од своје популарности и крај човјека више се није замишљао у том облику. Идеја суђења онда се одвојила од идеје васкрсења. (Ž. Delimo, Greh..., c. 129-130).

12 У пјесми Тужба краља Давида врху Абсалона такође говори о бесмислености богатства и неминовности умирања: Чему је све благо и злато на свиети и камен’је драго покли је умриети? (83-84) 
у прах ${ }^{13}$ смрт ће нас раздијелити са духом, наш стан ће бити тамо гдје су жабе и „шкарпјуни”, младост ће се угасити као свијећа. Истицањем трулежи тијела, човјека опомиње да је смртан, а истовремено га подстиче на презирање свијета, да би занемарио уживања у овоземаљском добру. Хришћанском концепцијом живота послије смрти опомиње оне који на вријеме нису мислили на посљедице, јер ће им не само тијело, већ и душе пасти у поноре:

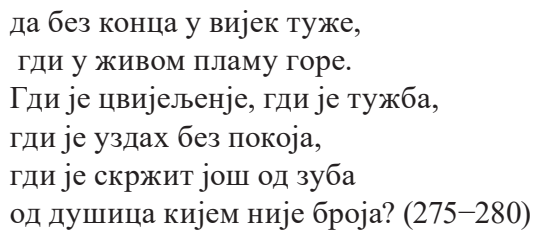

Наглашава да је свака слава и свако весеље попут цвијета на трави, па алегорично развија ту слику пролазности: цвијет на трави ,јутром зене”, у подне „прихини се”, а увече „вас повене, понизи се”. Тај цвијет више не мирише, сунце му „липос крати”, а увече увене и претвори се у прах ${ }^{14}$ (поново у библијском духу „Јер зна грађу нашу, опомиње да смо прах” 103.4)

Да се средњовјековно расположење мијења у правцу свјетовне чулности, чим се опомињање на пролазност не демонстрира на грозном лешу неког другог човјека, него се живи упућују на сопствено тијело - сада још лијепо, али ускоро предато црвима, како је примијетио Хојзинга, ${ }^{15}$ уочљиво је и код Ветрановића, у стиховима у којима критикује жене и њихов начин облачења:

Што ли прси и рамена

такој нага ви носите,

до сред мишце опражена,

покли у земљу походите? $(245-248)^{16}$

13 Хојзинга истиче да се дух средњовјековног човјека који је порицао свијет одувијек радо задржавао на прашини и црвима. Додаје да су у црквеним трактатима о презирању свијета већ били дочарани сви ужаси распадања, али да су приказивања појединости ове представе почела касније. Тако, тек крајем 14. вијека ликовна умјетност почиње да овладава овим мотивом. Ј. Хојзинга, Јесен средњега века, прев. С. Костић, Нови Сад 1991, с. 186.

14 У пјесми Млохаво је световно уфан'је користи исту алегорију:

али цвиет травице, ки зором процафти

тер лиепос на нице к вечеру обрати;

до сунца запада који цвиет гиздави

гоји се и влада цафтећи нарави,

прие сунце нер зајде тер лиепос прикрати.

тер свене и спаде и у прах се обрати. (23-28)

15 Ј. Хојзинга, Јесен..., с. 189.

16 Исту критику понавља и у пјесми Пјесаниа Aurea aetas:

Најлише гди жене садањијех врјемена

носе оплажене прси и рамена. (157-158)

Slavica Wratislaviensia 168, 2019

(C) for this edition by CNS 
Иако су гријехови, које конкретно наводи, различите тежине (једни су велики, други мањи, поједини спадају међу седам смртних), рекло би се да Ветрановић не прави никакву разлику међу њима. Сви су исти, због свих човјек страда, а међу првима помиње, понављајући их, раскош и блуд: „У раскошах и у блуду/жирите се још на вољу” (297-328). Претилост је, такође, један од гријехова, а доводи се у негативан контекст и у Светом писму, па се у псалму опомињу грешници ,Јер не знају за невољу до саме смрти, и тијело је њихово претило" (73: 4). Критикује и богатство, а затим је критику усмјерио ка судијама. Знао је да је њихово посрнуће велико (с обзиром на то да због новца не суде праведно), јер је за своје тумачење имао ослонац у стиху из псалма „Ко не даје сребра својега на добит, и не прима мита на правога. Ко овако ради, неће посрнути довијека". (15: 5). Као добар познавалац псалама, спознао је да је суштина човјековог битисања сталан страх од Бога, односно страх да се не учини гријех због ког би човјек био кажњен („Тајна је Господња у онијех који га се боје, и завјет свој јавља им” (25: 14), „Благо свакоме који се боји Господа, који ходи путовима његовијем!” (128: 1)), па је из тог разлога опоменуо судије, које узимају мито, а нису спознали овај страх:

\author{
У миту се ви топите \\ и митом се закладате, \\ а Бога се не бојите \\ и смрти се не надате. (325-328)
}

Не престаје да опомиње човјека да смрт „пријека грозно стријеља, грозно цвијели" и свакога стигне. Благо ће остати, а њихова ташта слава распашће се у прах.

Рефлексијама да ће смрт, када стигне, „све узгори дном обрати” и за кратко вријеме све уништити, попут пожара (све ће изгорјети, ништа неће остани), опомиње трговце, представљене као тврдице, да је узалуд скупљати благо. ${ }^{17}$ Своја размишљања завршава у библијском духу:

А нећете размишљати,

кад у гребу ви лежете,

да смрт неће ништор дати

да у земљу понесете? (325-328)

ослањајући се на стих из пслама: „Јер кад умре, неће ништа понијети, нити ће поћи за њим слава његова" (49: 17). ${ }^{18}$ Осим жеље да се обогате,

17 Злата Бојовић је примијетила да је одређеним сликовитим карактеристикама (немају мирног сна јер мисле о тргу и камати; иду како прасии док им одјећу наслагану у сандуцима једу мољци) Ветрановић антиципирао дубровачке литерарне ликове трговаца (Скупа, Дунда Мароја). 3. Бојовић, [предговор], [у:] Мавро Ветрановић, Поезија и драме, Београд 1994, с. 26.

${ }^{18}$ И ренесансне сликаре занимала је иста тема. Бош је насликао Смрт тврдице (Национална галерија умјетности, Вашингтон), у којој показује човјекову истрајност у лудости, чак и у тренутку смрти. Смртник лежи у соби у коју улази смрт. Анђео га 
трговци носе још један велики гријех - каматарење. Они, тврди Ветрановић, када пођу на спавање, не уживају у томе што имају, „ер о тргу и камати/ вашу памет заводите" (387-388). И о овом проблему, човјековом гријеху, Ветрановић је имао исти став, попут мислећих црквених људи. Жан Делимо примјећује да се у доба економског успона и заснивања трговачког капитализма хришћанска цивилизација забринуто питала о допуштености трговачких и банкарских трансакција. Због такве ситуације у том се подручју у великој мјери стварао осјећај кривице. Када се расправљало о овом гријеху, ослањало се на старе текстове. Друга књига Мојсијева (22, 25), Трећа къига Мојсијева (25, 35-37) и Пета кюига Мојсијева (23, 19-25) забрањивале су позајмљивање уз интерес међу Израиљцима. Такође су и оци грчки и латински говорили да зеленаш жање тамо гдје није сијао, да је позајмљивање уз интерес узимање туђег блага, да богаташ треба без надокнаде да позајмљује сиромаху и да је зеленаштво противно и религији и природном закону. Свети Тома Аквински сматра недопустивим да се при враћању позајмице тражи ма шта више од главнице. Свако позајмљивање уз интерес јесте зеленаштво и наводи на гријех не само зајмодавца већ и дужника. 19

Стиховима И напокон све зло прође пјесник завршава своје рефлексије о смрти, која ће доћи прије времена и прије рока. И на самом крају пјесме упозорава, овај пут присније (,моји дрази”), шта ће смрт учинити грешном смртнику:

\section{Моји дрази, тер смрт пријека \\ учинит ће у тој вријеме како нијемцем без језика ваша уста да занијеме. (409-412)}

Незадовољан понашањем суграђана, Ветрановић је испјевао Ремету другу и у њој образложио своја размишљања о смрти, а она слиједе средњовјековне и ренесансне религиозне списе Запада. Обезвређујући земаљске вриједности под утицајем contemptus mundi, упућује човјека на стално размишљање о гријеху. У својим ставовима ослања се на Свето nисмо. Макабристичким сликама инсистира на распадању тијела да би човјека подсјетио да је смртан и да су сва овоземаљска добра пролазна. Цијела пјесма, у ствари, одјек је memento mori.

Ремета друга представља илустрацију Ветрановићевих ставова о смрти и филозофију смрти оног дијела његове лирике у којој критички посматра понашање ренесансних распуштених људи, огрезлих у различите гријехове. Осуђује их у духу хришћанске ренесансе, не одобрава њихову наклоност према свјетовним задовољствима, показујући њихову безвриједност. У овој

придржава и показује му на распеће, али човјеку више пажњу привлаче овоземаљска добра, која мора да остави. Руку је пружио ка кеси злата коју му даје демон иза завјесе.

19 Ž. Delimo, Greh..., c. 330-342. 
својој најпознатијој сатиричној пјесми пјесник износи и религиозне ставове. Колико му је било битно да их изрази и нагласи, свједочи и често понављање и парафразирање стихова из Ремете друге у осталим пјесмама, па је на тај начин исту ствар у побожну сврху употријебио у сатиричној пјесми.

Ремета друга сигурно није остала незапажена код Ветрановићевих суграђана, будући да је њом на њих дидактички дјеловао, упозорио и упутио их на прави начин живота. Истовремено је створио добру подлогу генерацијама будућих пјесника, који ће у овој пјесми пронаћи сигуран ослонац за изношење својих ставова о смрти као неминовности, нарочито изражених у бароку.

\section{Библиографија}

Biderman H., Rečnik simbola, prev. M. Tarar-Tuтuš, H. Čopić, M. Živanović, Beograd 2004.

Bogišić R., Tema smrti u hrvatskoj renesansnoj poeziji, Zbornik radova posvećen Međunarodnom slavističkom kongresu u Varšavi, Zagreb 1973.

Bojović Z., [predgovor], [u:] Mavro Vetranović, Poezija i drame, Beograd 1994.

Bojović Z., Istorija dubrovačke književnosti, Beograd 2014.

Chevalier J. - Gheerbrant A., Rječnik simbola, prev. А. Буљан, Zagreb 1987.

Gof Le Ž., Srednjovekovna civilizacija zapadne Evrope, prev. D. Stošić, Novi Sad 2010.

Delimo Ž., Greh i strah, Stvaranje osećanja krivice na Zapadu od XIV do XVIII veka I, prev. Z. Jovanović, Novi Sad 1986.

Đorđević J., Kulturna etimologija reči macabre, Jezici i kulture u vremenu i prostoru II/1, Novi Sad 2013.

Hojzinga J., Jesen srednjega veka, prev. S. Kostić, Novi Sad 1991.

Pjesme Mavra Vetranića Čavčića, Dio I, Stari pisci hrvatski, knj. 3, Zagreb 1871.

Sveto pismo Staroga i Novoga zavjeta, Biblija, Sveti arhijerejski sinod Srpske pravoslavne crkve, Beograd 2012.

Švelec F., Mavro Vetranović, Radovi Instituta jugoslovenske akademije znanosti i umjetnosti u Zadru, Zagreb, 4-5, 1959, c. 175-214; VI-VII, 1960,

Oosterwijk S., Of Corpses, Constables and Kings: The Danse Macabre in Late Medieval and Renaissance Culture, „Journal of the British Archaeological Association” 157, 2004, c. 61-90.

\section{Reflections on death in the second Remeta of Ragusan poet Mavro Vetranović}

\section{Summary}

Ragusan poet Mavro Vetranović, as a representative of the Christian Renaissance, expressed in his poetry an appreciation of earthly life and he thought of death as an inevitability. These attitudes were present in both types of his lyrics, religious and mundane. The second Remeta was Vetranović's most famous satirical poem. Although it belongs to mundane lyrics, its function was to express a religious sentiment. Vetranović begins with general reflections on death, and then he develops this theme with effective comparisons, rhetoric questions and ingenious allegories. He makes it more tangible with a vision of death, armed with a scythe, cutting all around. Vetra- 
nović draws attention to human sin, as well as the only way of redemption, counting on wisdom from the Holy Bible. Renouncing earthly pleasures was one of the ways to fight against sin. The absurdity of pleasures was contrasted with naturalistic pictures of a dead man in a grave, of whom little would remain as no one can escape decomposition. He was trying to make people understand, by macabre pictures and images of rotten bodies, that they are mortal. At the same time, he motivated them, by preaching contemptus mundi, to despise and renounce all the pleasures of this life.

Keywords: death, reflection, Remeta, Mavro Vetranović

\section{Размышления о смерти в Ремете второй дубровницкого поэта Мавра Ветрановича}

\section{Резюме}

Дубровницкий поэт Мавро Ветранович, являясь представителем христианского Ренессанса, в своей поэзии раскрывал ничтожность земной жизни и размышлял о неминуемости смерти. Такое миропонимание отражается в его религиозной и светской лирике. Самым известным сатирическим стихотворением Ветрановича является Ремета вторая. Хотя оно относится к светской лирике, его функция заключается также в выражении религиозных представлений. В Ремете второй поэт размышляет о смерти, используя сравнения, риторические вопросы и остроумные аллегории, поэт рисует образ смерти с косой. Ветранович указывает человеку на его грехи, а также на путь к спасению, опираясь на Святое писание. Один из способов побороть грех заключается в отречении от всех мирских удовольствий. Мысль о бессмысленности мирских удовольствий подтверждается натуралистическим описанием мертвого человека. Смертность человека подчеркивается изображением жутких картин разложения тела. Одновременно, проповедуя contemptus mundi, поэт поощряет пренебрежение и презрение к наслаждению земными благами.

Ключевые слова: смерть, размышления, Ремета, Мавро Ветранович

Slavica Wratislaviensia 168, 2019

(C) for this edition by CNS 